\title{
Elementary School Teachers' Training Needs: Innovating Digital Competence
}

\author{
Yudin Citriadin', Mohammad Viktor Farid Hakim²
}

DOI: 10.35445/alishlah.v13i3.1485

Article Info

Keywords:

Digital Competence;

Need;

Teacher;

Training

Kata kunci:

Kompetensi Digital;

Kebutuhan;

Guru;

Pelatihan

\begin{abstract}
The purpose of the study was to determine the training needs needed by teachers in making digital products to facilitate the learning process. Training is as a way for teachers to innovate digital competencies. The participants of this study were 10 elementary school teachers $(\mathrm{F}=6$ and $\mathrm{M}=4)$. Participants are homeroom teachers from grades 1 to 6, and 4 were subject teachers (Mathematics, English, local content and sports). This study used the descriptive qualitative method. Observation, documents and interviews collected data. The data analysis process used the Miles and Huberman model through data reduction, data presentation, drawing conclusions and triangulation. The results show that teachers need workshops that can directly practice making digital teaching tools such as learning videos and developing videos on the YouTube channel. However, they have difficulties with the technological devices they have. There are $30 \%$ of teachers who have full technology equipment, and the rest rely on smartphones for online teaching and learning. Thus, schools can consider providing technology tools that teachers can use in developing digital competencies and digital learning tools.
\end{abstract}

\begin{abstract}
Abstrak
Penelitian ini bertujuan untuk mengetahui kebutuhan pelatihan yang dibutuhkan guru dalam membuat produk digital untuk memfasilitasi proses pembelajaran. Pelatihan sebagai cara bagi guru dalam melakukan inovasi kompetensi digital. Partisipan penelitian ini adalah 10 guru Sekolah Dasar $(\mathrm{F}=6$ dan $\mathrm{M}=4)$. Peserta adalah wali kelas dari kelas 1 sampai 6 , dan 4 adalah guru mata pelajaran (Matematika, Bahasa Inggris, muatan lokal dan olahraga). Penelitian ini menggunakan metode deskriptif kualitatif. Pengumpulan data dilakukan dengan observasi, dokumen dan wawancara. Proses analisis data menggunakan model Miles dan Huberman melalui proses reduksi data, penyajian data, penarikan kesimpulan dan triangulasi. Hasil penelitian menunjukkan bahwa para guru membutuhkan workshop yang bisa langsung praktek membuat alat pengajaran digital seperti video pembelajaran dan mengembangkan video pembelajaran itu di kanal YouTube. Namun, mereka memiliki kesulitan dari perangkat teknologi yang dimilikinya. Ada 30\% guru yang memiliki perangkat teknologi lengkap dan sisanya mengandalkan telepon pintar untuk pengajaran dan pembelajaran daring. Jadi, sekolah bisa mempertimbangkan untuk menyediakan perangkat teknologi di sekolah yang bisa dimanfaatkan oleh para guru dalam mengembangkan kompetensi digital serta alat pembelajaran digital.
\end{abstract}

\footnotetext{
${ }^{1}$ Manajemen Pendidikan, UIN Mataram, Indonesia

Email: Yudin.citriadin@uinmataram.ac.id

2 Manajemen Pendidikan, UIN Mataram, Indonesia

Email: mohammadviktorfaridh@gmail.com
} 


\section{INTRODUCTION}

Multimedia technology has now become a must for teachers in online classes. The learning process using various technology applications cannot be avoided because online learning activities are still being carried out. Moreover, the Covid-19 pandemic has not shown any change for the better. The Covid-19 pandemic has made humans adjust their behaviour, especially in education. Changes in learning activities from a face-to-face system to an online system greatly impact student psychology, especially interest in learning (Ru'iya et al., 2021). Therefore, teachers must create interesting online classes and prepare teaching materials that can attract students' interest and motivation to learn. Moreover, elementary school students have a unique and different personality level from middle-level students (Yu \& Zhang, 2021). So, elementary school teachers are required to present interesting online learning classes with the help of multimedia technology. This means that the global and digital era requires every educator to have digital competence. Thus, this can positively impact pedagogic competence, personality competence, social competence, and professional competence that teachers must possess.

Therefore, every school must carry out activities to increase teachers' digital competence through various training or other activities. The use of digital technology has become an urgent demand in this changing world. Changes in the teacher's role, from traditional to digital, requires systematic procedures and training. So, there needs to be a strategy to meet the training needs and design a training course. It also investigates the reasons that forced these changes in the roles of teachers and the competencies and skills they must possess (Bader, 2021). The general problems of pedagogical challenges are principally related to the lack of digital skills of teachers and students, the lack of structured content versus the abundance of online resources, the lack of student interactivity and motivation, and the lack of social interaction and teacher learning (Ramanlingam, 2021)

From the results of learning observations and interviews with teachers and principals at Tan Nujaba Islamic Elementary School, it was concluded that teachers need the training to help make learning videos, and they need knowledge related to current technological developments in the world of education. In addition, the teachers assessed that learning outcomes in the 2020-2021 school year were quite apprehensive due to the limitations of technological devices. In addition, according to the principal, teachers have not yet made creative learning videos; moreover, schools rarely carry out training activities related to digital competency needs.

Thus, the discussions with school principals revealed that they needed training related to increasing digital competence. To get the right type of training, this research was conducted so that the concept of teacher training at Tan Nujaba Islamic Elementary School was carried out according to the teacher's needs. In addition, the diversity of teacher backgrounds differs in terms of age, ability, ownership of technology devices, and skills they possess. These reasons are the basis for carrying out this research activity. Training held according to the needs and interests of teachers can make changes to their competencies (Suyitno et al., 2017). The concept of training can have an impact on teacher competence. Hybrid learning training strategies like this can have a positive impact because, in hybrid learning, we can combine face-to-face and online training. Training activities can also be used as a form of teacher professional development and teacher competency improvement (Mulhayatiah et al., 2021).

Currently, teachers have some difficulties with the dimensions related to content creation (GalindoDomínguez \& Bezanilla, 2021). Therefore, training related to digital competence will assist teachers in developing their technical knowledge that can be implemented in teaching quality. Training activities can be made by the government or schools (Chaikovska et al., 2021). The current state of the pandemic has brought about an increase in the need for digital skills training and the need for training for digital skills enhancement compared to the previous academic year. However, the adoption of online activities comes with various challenges ranging from the organization's internal IT infrastructure, internet connection bandwidth, cybersecurity, and employee digital skills (Carutasu et al., 2021). Digital technology is a tool and an environment for the existence of a modern person, which opens up new opportunities: learning at any time, continuing education, the ability to form an individual educational 
route, from a user of electronic resources to creator. So, teachers are required to acquire new skills and abilities to work in the digital education space (Vasiljanovna, 2021). Moreover, today's students as digital natives have digital experiences that teachers can use as resources in implementing their digital professionals and competencies (Almås et al., 2021). Based on the exposure to the results of previous studies, it can be concluded that training is one way to improve the competence of educators. Especially in the era of technology, all human activities have involved technological devices.

In this study, the concept of training that is by the context of teacher needs, conditions in the elementary school area, the level of ability of everyone in the school related to the use of technology devices. So, this study aims to obtain training needs related to digital competencies that teachers must possess. The results of this study are also expected to provide benefits for teachers or schools regarding the development of video teaching materials for online and offline teaching and learning activities.

\section{METHOD}

Research participants were all 10 teachers in Islamic Elementary School at Mataram ( $\mathrm{F}=6$ and $\mathrm{M}=4$ ). Participants are homeroom teachers from grades 1 to 6 , and 4 are subject teachers (mathematics, English, local content and sports). Participants were taken randomly with the criteria: 1) classroom teacher, 2) special subject teacher, 3) 30-50 years old, and 4) possessing technology. The research was conducted in March - April 2021. So, this research used qualitative method with descriptive case study methods (Yin, 2011), because it examines various facts related to the needs of teacher training specifically for innovating digital competence. As stated by Creswell \& Creswell (2018), qualitative research leads to the study of phenomena or facts in the field.

Data were collected using observations, documents and interviews. Observation activities were carried out for 2 weeks to observe the online learning and teaching process. Documents are materials or worksheets and supervision used by teachers during online learning. Interviews were given to participants using closed-ended questions. The process of data analysis uses the Miles and Huberman model through the process of data reduction, data presentation, drawing conclusions and triangulation (Miles \& Huberman, 1994).

\section{FINDING AND DISCUSSION}

The analysis of observational data related to the online teaching and learning process shows that online teaching teachers at Tan Nujaba Islamic Elementary School in the 2020-2021 school year have not utilized technology. Learning activities have not used technology applications. Some of the findings from the observations are:

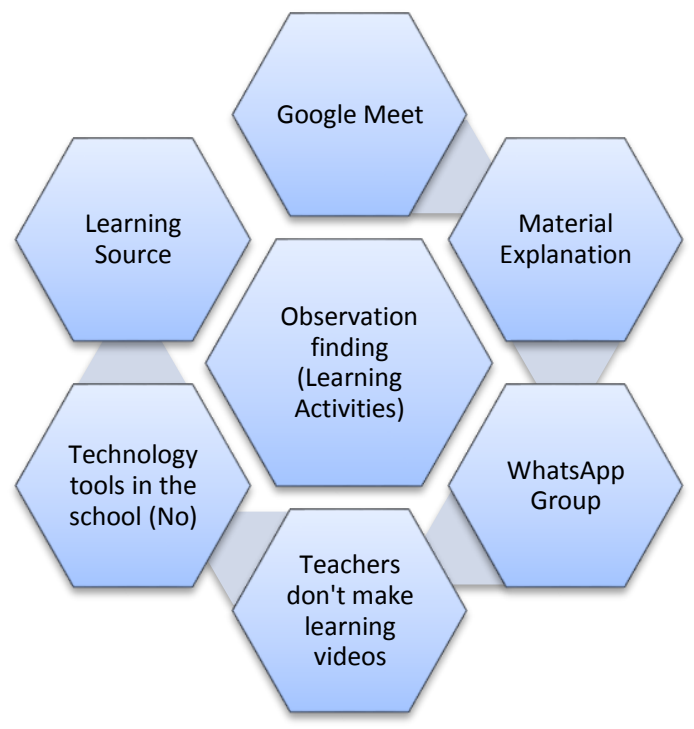

Picture 1. The result of observation for learning activities 
1. Google Meet is used before the end of semester exams

2. The material is explained through voice notes in the WhatsApp group.

3. The teacher gives directions for studying the material from the students' books and worksheets through the WA group.

4. The teacher has never made a learning video

5. Schools have not used technology applications for online learning activities.

Meanwhile, the results of the data analysis of the teaching materials used so far are still using printed books and Student Worksheets. Whereas as we know, the online learning process for elementary schools requires multimedia assistance to have the motivation and interest in learning. During the online learning period, factors-in-class interaction, student motivation, course structure, instructor knowledge, and facilitation-positively affect perceptions of student learning outcomes and student satisfaction (Baber, 2020). Fajri et al. (2021) showed that interest and motivation to learn remained good with the learning process through zoom cloud meetings.

Following are the results of interviews with participants:

1. What type of training do you need related to your digital competency innovation?

Types of Training

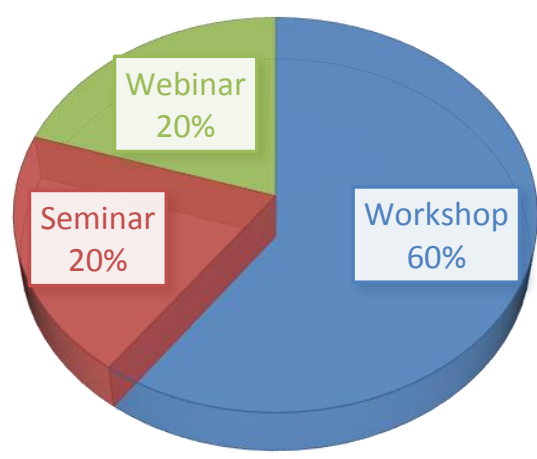

\section{Graph 1. Types of Training for Innovating of Digital Competence}

Graph 1 shows that teachers need workshops related to the innovation of their digital skills. The interview results found that the workshop was the right training activity for teachers because the workshop process involved practice in the field or the practice of doing works. Thus, teachers find it easier to develop the work created. Moreover, IT-based training focuses on technical and software aspects of pedagogical improvement (Keengwe \& Georgina, 2012).

Interview Result:

Teacher:

"We prefer workshops because we can directly practice making products and be guided directly. If we have difficulties, we can also directly ask and make improvements to our work."

"We need training that is able to direct us digital competency development so that teaching and learning activities can be relevant to current conditions."

From these findings, it can be understood that this type of teacher training in all areas should include advanced digital competencies for teachers and their teaching, not only concentrating on the skills of teachers' ICT users. Training should consider aspects of using ICT both as a learning tool in teaching subjects and as a tool used by students for their homework and actions related to learning outside of school. This finding is relevant to Tammaro \& D'Alessio (2016) study that the training for ICT skills that teachers must possess is not only related to technical knowledge but how the results of developing ICT competencies have an impact on the teaching and learning process. 
2. What training activities do you need related to the subjects you teach?

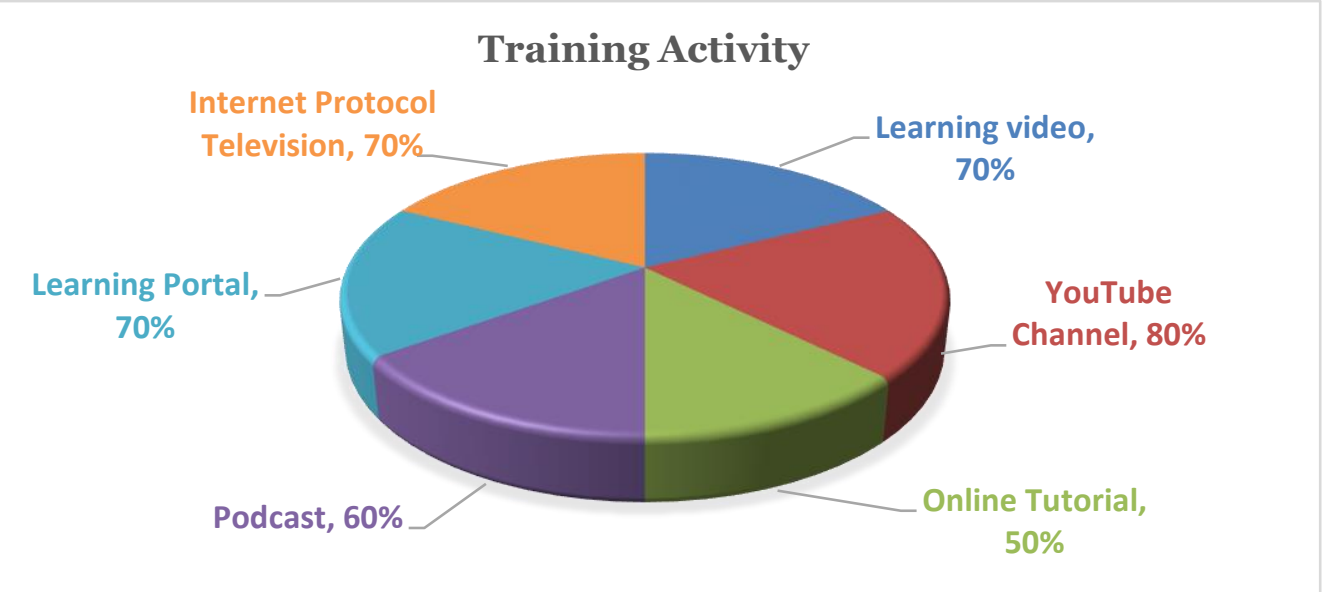

\section{Graph 2. Types of Training Activity for Innovating of Digital Competence}

Graph 2 concludes that teachers need various activities related to developing or making digital applications or using existing digital technology. The data shows that teachers need training related to making learning videos. Because learning videos can help students learn more efficiently, and students can understand the material (Fadillah \& Maryanti, 2021).

3. Do you have the technology tools to develop digital learning products?

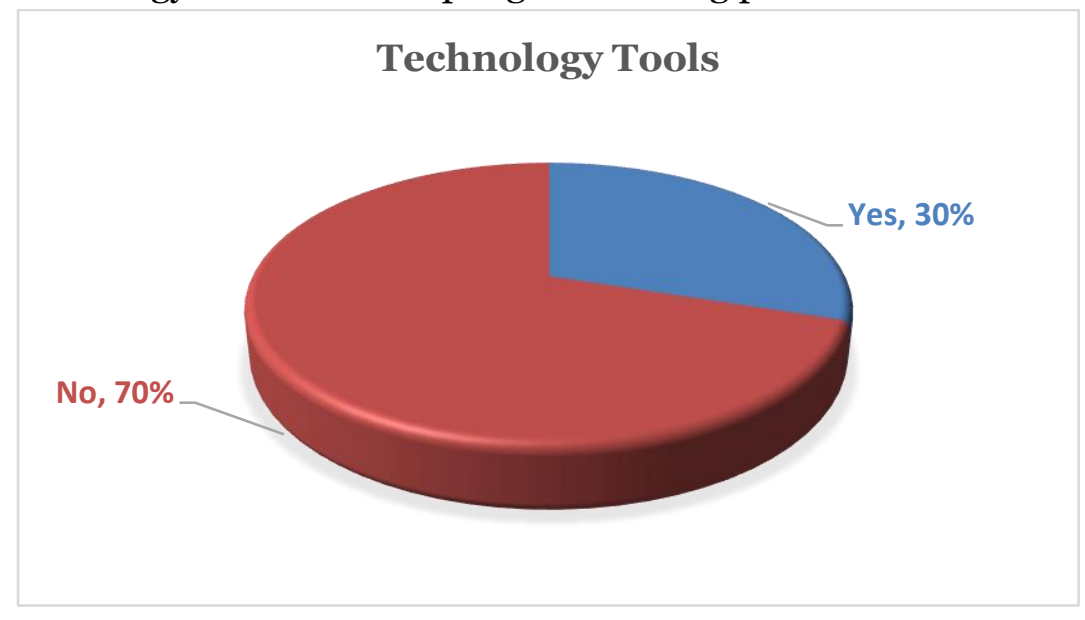

\section{Graph 3. Technology Tools for Teachers}

Teachers do not yet have complete technology tools. Of the 10 teachers interviewed, 3 people have complete technology equipment in their homes and 7 people do not have technology equipment. They only use smartphones to carry out online learning activities. Therefore, they highly expect training and technological support from the school. Today's digital transformation has implications for how and what to teach. Technology as a teaching tool and as a teaching content (Guggemos \& Seufert, 2021). Teachers actively seek to resolve demanding situations by going beyond their current Professional Digital Competencies through engagement in various forms of digital transformative agency (Brevik et al., 2019). Digital competency development, whether implemented in primary schools, in other forms of early education or even further education, is targeted at the respective educational impact entities and appropriate levels of digital literacy (Rambousek et al., 2015).

\section{CONCLUSION}

The study results concluded that teachers need this type of training. These namely workshops can directly practice making digital teaching tools such as learning videos and developing learning videos on the YouTube channel. However, they have difficulty with the technological tools they must have. There are $30 \%$ of teachers who have full technology equipment and the rest rely on smartphones 
for online teaching and learning. Therefore, from these findings, it is recommended that schools be provided with complete technological tools so that teachers can use these devices to develop digital products or learning tools. Schools can also create special teams for training or ongoing activities related to the manufacture of digital learning tools products according to the abilities of students and the learning environment at school. This means that students can access and use digital learning tools without making it difficult for them to relate to technological devices or internet networks.

The results of this study still have limitations because the study focused on the training needed by teachers in making digital learning products to facilitate the online learning process. Therefore, further researchers can develop this research related to the strengths or weaknesses of schools in providing programs to improve the quality of teaching resources. Schools can also use the results of this research to develop teacher digital competency quality programs in the global era because the Covid-19 pandemic has not shown any improvement in learning conditions.

\section{REFERENCES}

Almås, A. G., Bueie, A. A., \& Aagaard, T. (2021). From digital competence to Professional Digital Competence. In Nordic Journal of Comparative and International Education (NJCIE) (Vol. 5, Issue 4, pp. 70-85). OsloMet - Oslo Metropolitan University. https://doi.org/10.7577/njcie.4233

Baber, H. (2020). Determinants of students' perceived learning outcome and satisfaction in online learning during the pandemic of COVID19. Journal of Education and E-Learning Research, 7(3), 285-292. https://doi.org/10.20448/JOURNAL.509.2020.73.285.292

Bader, S. A. B. S. A. (2021). Training Needs for the Digital Teacher: الرقمي للمعلم التدريبية الاحتياجات. In مجلة النفسية و التربوية العلوم (Vol. 5, Issue 32, p. 155). The Arab Journal of Sciences and Research Publishing. https://doi.org/10.26389/ajsrp.m150321

Brevik, L. M., Gudmundsdottir, G. B., Lund, A., \& Strømme, T. A. (2019). Transformative agency in teacher education: Fostering professional digital competence. Teaching and Teacher Education, 86, 102875. https://doi.org/10.1016/J.TATE.2019.07.005

Carutasu, G., Cotet, G. B., \& Carutasu, N. L. (2021). Pandemic Impact Over Digital Skills Training Needs. In INTED2O21 Proceedings. IATED. https://doi.org/10.21125/inted.2021.0130

Chaikovska, O., Tolmach, M., \& Bondar, I. (2021). Digital Competence Training In Ukraine: The Dcomfra Project Experience. ICERI2O21 Proceedings. https://doi.org/10.21125/iceri.2021.1594

Creswell, J. W., \& Creswell, J. D. (2018). Research design: Qualitative, quantitative, and mixed methods approaches fifth edition. SAGE Publications Inc.

Fadillah, I. N., \& Maryanti, R. (2021). Application of Learning Videos and Quizizz in Increasing Students Interest in Learning English in Middle Schools. Indonesian Journal of Multidiciplinary Research, 1(2), 329-336. https://ejournal.upi.edu/index.php/IJOMR/article/view/37853

Fajri, Z., Baharun, H., Muali, C., Shofiatun, Farida, L., \& Wahyuningtiyas, Y. (2021). Student's Learning Motivation and Interest; The Effectiveness of Online Learning during COVID-19 Pandemic. Journal of Physics: Conference Series, 1899(1), 012178. https://doi.org/10.1088/1742-6596/1899/1/012178

Galindo-Domínguez, H., \& Bezanilla, M. J. (2021). Digital competence in the training of pre-service teachers: Perceptions of students in the degrees of early childhood education and primary education. In Journal of Digital Learning in Teacher Education (pp. 1-16). Informa UK Limited. https://doi.org/10.1080/21532974.2021.1934757

Guggemos, J., \& Seufert, S. (2021). Teaching with and teaching about technology - Evidence for professional development of in-service teachers. Computers in Human Behavior, 115, 106613. https://doi.org/10.1016/j.chb.2020.106613

Keengwe, J., \& Georgina, D. (2012). The digital course training workshop for online learning and teaching. Education and Information Technologies, 17(4), 365-379. https://doi.org/10.1007/s10639-011-9164-x

Miles, M. B., \& Huberman, A. M. (1994). Qualitative Data Analysis; An Expanded Sourcebook. Sage Publication.

Mulhayatiah, D., Sinaga, P., Rusdiana, D., Kaniawati, I., \& Suhendi, H. Y. (2021). Pedagogical and professional physics teacher training: Why hybrid learning is important? Journal of Physics: Conference Series, 1806(1). https://doi.org/10.1088/1742-6596/1806/1/012036

RAMANLINGAM, S. (2021). Remote teaching \& digital platform during pandemic Teacher education 
and teacher competence effects among teachers \& principles in Malaysia. In Advances in Social Sciences Research Journal (Vol. 8, Issue 5, pp. 457-472). Scholar Publishing. https://doi.org/10.14738/assrj.85.10246

Rambousek, V., Štípek, J., \& Wildová, R. (2015). ICT Competencies and their Development in Primary and Lower-secondary Schools in the Czech Republic. Procedia - Social and Behavioral Sciences, 171, 535-542. https://doi.org/10.1016/J.SBSPRO.2015.01.158

Ru'iya, S., Kistoro, H. C. A., Sutarman, S., \& Maulana, L. A. (2021). The effort to increase the students' interest in learning during the Covid-19 pandemic through comic media. Community Empowerment, 6(6), 1021-1028. https://doi.org/10.31603/CE.4914

Suyitno, A., Sugiharti, E., \& Pujiastuti, E. (2017). Elementary School Teacher Training Based on Needs and Interests of Teachers and The Effectiveness of The Improvement of Students Competence. Journal of Physics: Conference Series, 824(1), 012051. https://doi.org/10.1088/17426596/824/1/012051

Tammaro, R., \& D’Alessio, A. (2016). Teacher Training and Digital Competence. In International Journal of Digital Literacy and Digital Competence (Vol. 7, Issue 2, pp. 1-10). IGI Global. https://doi.org/10.4018/ijdldc.2016040101

Vasiljanovna, E. G. (2021). Digital competence of the future teacher: Component composition. ACADEMICIA: An International Multidisciplinary Research Journal, 11(6), 330-337. https://doi.org/10.5958/2249-7137.2021.01622.0

Yin, R. K. (2011). Aplikasi penelitian studi kasus. Thousand Oak.

Yu, Y., \& Zhang, Y. (2021). Personality and Developmental Characteristics of Primary School Students' Personality Types. Frontiers in Psychology, 12, 693329. https://doi.org/10.3389/FPSYG.2021.693329 
Al- Ishlah: Jurnal Pendidikan, December 2021, 13 (3), Pages 2327-2334

Yudin Citriadin, Mohammad Viktor Farid Hakim

This page is intentionally left blank 